\title{
Editorial
}

\section{A Especialização em Medicina Veterinária}

"O especialista é uma engrenagem competente que não emperra, e que, dos seus limites compartilha, com humildade e respeito, do trabalho da máquina profissional".

Nestes novos tempos da Medicina Veterinária quando, cada vez mais, surgem inúmeras novas fontes de conhecimento técnico-científico e, consequentemente, o "saber" e os currículos profissionais se avolumam, não há como negar que o "generalista" veterinário sucumbiu de vez.

Não há como dominar tantas matérias sobre tantas espécies de animais domésticos, de laboratório e silvestres.

O "generalista" que, obviamente, nunca atuaria em Instituições com atividades especializadas, notadamente naquelas de ensino e/ou pesquisa, está sendo substituído pelo "especialista" que traz consigo uma marca: - a competência. Esta marca que o faz "mandar" no mercado de trabalho é capaz de experimentar uma emóção humana nobre e desconhecida da maioria: A "satisfação profissional". Esta satisfação que se completa quando, como seres gregários que somos, trabalhamos em "equipe" e temos a dádiva de exercitar a difícil arte do relacionamento humano.

Antes, no Brasil, quando éramos poucos Veterinários e que, até mesmo pelo juramento firmado nas solenidades de colação de grau, não podíamos frustrar quem nos solicitasse os préstimos, não havia como dizer: - esta não é minha área de atuação, vou encaminhá-lo a um colega "especialista". Hoje, pelo menos nos grandes centros, a atividade generalista não é concebível, já que somos numericamente suficientes para cobrir as mais diferentes especialidades: as médico-veterinárias propriamente ditas, as de tecnologia e higiene veterinária e as de produção de alimentos de origem animal. Este é, indubitavelmente, um currículo profissional grande, assim como, um grande currículo.

No entanto, a concepção de "especialidade" não se imporá jamais, se o Veterinário não trouxer consigo a visão do todo profissional, a cultura médicoveterinária geral, ou mesmo o conhecimento correto das intercorrências técnicas das especialidades.

Eulógio Carlos Queiroz de Carvalho Prof. Titular do MPT/UFF

Serviço de Anatomia Patológica Veterinária Prof. Jefferson Andrade dos Santos 